\title{
Kinerja Mengajar dengan Sistem Work From Home (WFH) pada Guru di SMK Purnawarman Purwakarta
}

\author{
Sarah Busyra ${ }^{1}$, Lutfiah Sani² \\ ${ }^{1}$ Pascasarjana, Universitas Islam Negeri Sunan Kalijaga Yogyakarta, Indonesia \\ ${ }^{2}$ Pascasarjana, Universitas Islam Negeri Sunan Kalijaga Yogyakarta, Indonesia \\ ${ }^{1}$ sarahbusyra88@gmail.com \\ ${ }^{2} 1 . s a n i a s m a 99 @$ gmail.com
}

\begin{abstract}
Abstrak:
Artikel ini mencoba untuk mengidentifikasi kinerja mengajar guru di SMK Purnawarman Purwakarta menggunakan sistem Work From Home (WFH) selama pandemi Covid-19. Populasi penelitian ini adalah guru di SMK Purnawarman Purwakarta yang berjumlah 22 orang. Metode penelitian menggunakan rancangan metode campuran Sekunsial Eksplanatori, yang mana data kualitatif dapat menerangkan lebih lanjut atau memperkuat data kuantitatif awal. Penyajian hasil dari penelitian ini menggunakan analisis statistik deksriptif dengan bentuk deskriptif kuantitatif yang dikolaborasikan dengan deskriptif analisis data kualtitatif. Teknik pengumpulan data menggunakan kuesioner, wawancara dan dokumentasi berupa data sekolah. Hasil penelitian ini menunjukkan bahwa rata-rata kinerja guru dalam mengajar menggunakan sistem work from home hanya mencapai 50\%. Secara keseluruhan, hasil kinerja tidak melebihi batas $70 \%$. Hal itu terjadi karena beberapa faktor yaitu hampir sebagian besar dari guru tidak memahami beberapa aplikasi yang digunakan dalam mengajar, serta jarak yang menyebabkan guru menghadapi hambatan dalam berinteraksi dengan siswa secara optimal.
\end{abstract}

Kata Kunci: Kinerja Mengajar, Sistem Work From Home, Pandemi Covid-19

\begin{abstract}
:
This article tries to identify the teaching performance of teachers at SMK Purnawarman Purwakarta using the Work From Home (WFH) system during the Covid-19 pandemic. The population of this study is teachers at SMK Purnawarman Purwakarta which is 22 teachers. The method used mixture of Explanation Sequential, which is qualitative data can explain further more or strengthen the initial quantitative data. The results ot this study used descriptive statistical analysis with quantitative descriptive forms that are collaborated with descriptive qualitative data analysis. Data collection techniques using questionnaires, interviews and documentation in the form of school data. The results of this study showed the average performance of teachers in teaching using work from home system is only $50 \%$. Overall, the performance results do not exceed the $70 \%$ limit. It happened because several factors are the half of the teachers do not understand some applications that used in teaching, also the distances caused the teachers face obstacles in interaction with students optimally.
\end{abstract}

Keywords: The Teaching Performances, Work From Home System, Pandemic Covid-19 
Syarah Busyra, Lutfiah Sani

\section{Pendahuluan}

Mewabahnya virus Corona (Covid-19) yang melanda sebagian besar negara di dunia membuat umat manusia berada dalam kesedihan dan kecemasan mendalam. ${ }^{1}$ Social distancing atau yang biasa pula disebut sebagai pembatasan jarak sosial maupun physical distansing atau pembatasan jarak fisik telah sedemikian ripa dirancang demi mengurangi interaksi langsung antara masyarakat luas, karena setiap individu berpotensi sebagai carrier atau yang menularkan virus bahkan menjadi pasien tertular tanpa gejala. ${ }^{2}$ Hal ini sangatlah berbahaya mengingat penularan virus tersebut tergolong mudah yaitu dengan berbagai macam kontak fisik. Namun hal ini masih diupayakan pencegahannya. Salah satunya adalah yang juga diterapkan oleh Indonesia yaitu himbauan untuk bekerja dari rumah, belajar dari rumah dan juga tidak meramaikan tempat peribadatan. ${ }^{3}$ Pada masa pandemic Covid-19, sejumlah akademisi telah menerbitkan karya ilmiah mengenai sistem Work from Home (WFH). Istilah Work From Home pertama kali dikenal sejak menyebarnya virus SARS-CoV-2. Beberapa menjelaskan dengan rinci mengenai pembelajaran online saat ini. Pada masa Work From Home (WFH), seluruh tingkatan pendidikan mulai dari dasar hingga pendidikan tinggi perlu melakukan penguatan pembelajaran secara daring. ${ }^{4}$ Sebenarnya pembelajaran model ini bukan hal yang benar-benar baru. Belajar dengan media internet telah menjadi wacana anjuran dunia pendidikan selama beberapa tahun belakangan. ${ }^{5}$ Hal ini disebabkan karena cara belajar secara langsung atau yang biasa dikatakan tatap muka dirasa tertinggal zaman dan dianggap sebagai model pembelajaran yang kurang maju, sehingga diusunglah wacana pembelajaran menggunakan media pembelajaran yang lebih baik dengan memanfaatkan teknologi informasi modern ${ }^{6}$, seperti menggunakan smartphone, internet dan berbagai aplikasi pendukung sistem daring masa kini.

Akan tetapi, hal ini mendapat berbagai komentar dan sanggahan berdasarkan hal-hal yang terjadi dilapangan. Banyak kendala dihadapi oleh pihak sekolah, guru maupun siswi dan

\footnotetext{
${ }^{1}$ Elisabeth Mahase, Coronavirus: covid-19 has killed more people than SARS and MERS combined, despite lower case fatality rate (British Medical Journal Publishing Group, 2020).p. 1

2 Annelies Wilder-Smith dan David O. Freedman, "Isolation, quarantine, social distancing and community containment: pivotal role for old-style public health measures in the novel coronavirus (2019-nCoV) outbreak," Journal of travel medicine 27, no. 2 (2020): taaa020.p. 1

${ }^{3}$ Wahyudin Darmalaksana, "Corona Hadis," Fakultas Ushuluddin UIN Sunan Gunung Djati Bandung, 2020.p. 2

4 Wahyudin Darmalaksana, "WhatsApp Kuliah Mobile," Fakultas Ushuluddin UIN Sunan Gunung Djati Bandung, 2020.

${ }^{5} \mathrm{Wu}$ He, Guandong Xu, dan S. E. Kruck, "Online IS education for the 21st century," Journal of Information Systems Education 25, no. 2 (2019): 1.

${ }^{6}$ Ritanjali Panigrahi, Praveen Ranjan Srivastava, dan Dheeraj Sharma, “Online learning: Adoption, continuance, and learning outcome-A review of literature," International Journal of Information Management 43 (2018): 114.
} 
para orang tua. Salah satunya kebiasaan anak yang lebih fokus belajar saat dihadiri langsung dan mendengarkan penjelasan guru. Hal ini tentunya sangat mempengaruhi hasil belajar siswa, ${ }^{7}$ melihat proses dan kinerja pembelajaran yang dilakukan oleh para guru juga belum bisa dikatakan maksimal dikarenakan berbagai halangan. Meskipun fasilitas pengajarannya lengkap dan canggih, namun bila tidak ditunjang oleh keberadaan guru yang berkinerja baik, maka mustahil akan menimbulkan proses belajar dan pembelajaran yang maksimal. ${ }^{8}$ Pada hakikatnya, kinerja guru ini banyak dipengaruhi oleh berbagai faktor baik faktor internal maupun faktor eksternal individu yang bersangkutan. ${ }^{9}$ Hal ini adalah salah satu faktor eksternal yang dialami para guru, tetapi secara professional sang guru tetaplah guru yang harus bisa mengerahkan seluruh kemampuannya saat mentransfer pelajaran.

Media daring sangat memberikan dampak terhadap kinerja guru dalam mengajar. Empat kemampuan (profesionalitas) guru, penguasaan materi dan sikap guru diuji secara 'paksa' saat masa pandemi Covid-19 terjadi. SMK Purnawarman Purwakarta merupakan salah satu Sekolah Menengah Kejuruan yang menerapkan pembelajaran daring (online) kepada para siswanya. Sebagai bagian dari sistem pendidikan nasional, SMK merupakan pendidikan menengah yang mempersiapkan peserta didik untuk terfokus bekerja pada bidang tertentu, dapat menyesuaikan dengan lingkungan kerja, jeli dalam menangkap peluang kerja dan dapat mengembangkan diri di masa mendatang. Maka dari uraian latar belakang masalah di atas, kami akan melakukan penelitian mengenai dampak sistem work from home (WFH) terhadap kinerja mengajar guru di SMK Purnawarman Purwakarta saat masa pandemi Covid-19.

Berdasarkan data yang telah dikumpulkan oleh penulis, sekiranya perlu diteliti bagaimana kinerja mengajar guru pada masa pandemi, faktor apakah yang mempengaruhi kinerja mengajar guru di SMK Purnawarman Purwakarta serta dampak apa saja yang muncul dari diberlakukannya sistem work from home (WFH) terhadap kinerja mengajar guru di SMK Purnawarman Purwakarta saat masa pandemi Covid-19. Penelitian ini bertujuan untuk mencari titik permasalahan yang menjadi kendala, faktor-faktornya serta dampak yang ditimbulkan. Manfaat dari penelitian ini adalah untuk memperkaya khazanah keilmuan dan literasi di bidang pendidikan khususnya pada masa pandemi ini. Dan juga sebagai perpanjangan saran kepada

\footnotetext{
${ }^{7}$ Alodia Sc, "Dasar Dasar Proses Belajar Mengajar Oleh Nana Sudjana Penyunting Harry Suryana," 42, diakses 4 Juli 2020, https://www.academia.edu/11365221/Dasar_dasar_proses_belajar_mengajar_Oleh_Nana_Sudjana_penyunting Harry_Suryana.

${ }^{8}$ Destia Nur Raisyifa dan Nani Sutarni, "Pengaruh kinerja mengajar guru terhadap motivasi belajar siswa," Jurnal Pendidikan Manajemen Perkantoran (JPManper) 1, no. 1 (2016): 279.

${ }^{9}$ Hary Susanto, "Faktor-faktor yang mempengaruhi kinerja guru sekolah menengah kejuruan," Jurnal Pendidikan Vokasi 2, no. 2 (2012): 198.
} 
pihak-pihak akademisi dan dinas pendidikan yang masih terus berupaya memperbaiki sistem pendidikan di Indonesia khususnya.

\section{Kinerja Mengajar}

Profesi guru telah disebutkan dalam UU Nomor 14 tahun 2005 Bab 1 Pasal 1. Undangundang tersebut menuliskan bahwa guru adalah pendidik profesional yang memiliki tugas utama untuk mendidik, mengajar, membimbing, mengarahkan, melatih, menilai, dan juga mengevaluasi peserta didik baik itu pendidikan anak usia dini jalur pendidikan formal, maupun pendidikan dasar, dan pendidikan menengah. ${ }^{10}$ Ini artinya seorang guru memiliki peran penting dalam menyukseskan pendidikan khususnya di Indonesia. Karena kualitas seorang guru sangat berkaitan erat dengan kualitas pendidikan di suatu Negara. Dengan kata lain, guru merupakan ujung tombak untuk meningkatkan kualitas layanan dan hasil pendidikan. Dalam berbagai literature juga banyak disebutkan bahwa kualitas sistem pendidikan secara keseluruhan berkaitan dengan kualitas guru. ${ }^{11}$

Guru merupakan garda terdepan dalam pengembangan diri anak dengan memberikan berbagai macam pengetahuan dan keterampilan serta pembentukan kepribadian. Maka guru memiliki tuntutan untuk mempersiapkan segenap kemampuannya demi melaksanakan pendidikan dan bimbingan kepada anak didiknya. Guru harus memiliki berbagai kemampuan dalam kegiatan pembelajaran di antaranya adalah kemampuan profesional yang meliputi penguasaan materi pembelajaran, strategi pembelajaran, penguasaan metode, penguasaan bimbingan dan penyuluhan serta penguasaan evaluasi pembelajaran. ${ }^{12}$ Tujuan pendidikan akan dapat tercapai dan terlaksana apabila seorang guru bekerja secara sungguh-sungguh, rajin, dan dengan sepenuh hati. ${ }^{13}$

Segala kemampuan guru yang terealisasikan dapat disebut dengan kinerja guru. Kinerja guru menjadi salah satu faktor penting dalam meningkatkan mutu pendidikan di Indonesia, khususnya pada diri peserta didik, ${ }^{14}$ Pendapat Byars dan Rue yang dikutip dalam salah satu penelitian menyatakan bahwa kinerja adalah sesuatu yang menggambarkan tingkatan

\footnotetext{
${ }^{10}$ Susanto, 200.

${ }^{11}$ Badrun Kartowagiran, "Kinerja guru profesional (Guru pasca sertifikasi)," Jurnal Cakrawala Pendidikan 3, no. 3 (2011): 463.

12 Laode Ismail Ahmad, "KONSEP PENILAIAN KINERJA GURU DAN FAKTOR YANG MEMPENGARUHINYA," Idaarah: Jurnal Manajemen Pendidikan 1, no. 1 (14 Juni 2017): 137, https://doi.org/10.24252/idaarah.v1i1.4133.

${ }_{13}$ Ahmad, 138-39.

${ }^{14}$ Susanto, "Faktor-faktor yang mempengaruhi kinerja guru sekolah menengah kejuruan," 200.
} 
pencapaian dalam penyelesaian pekerjaan seseorang. Maka kinerja memberikan gambaran seberapa baik seseorang dalam menyelesaikan tuntutan suatu kewajiban. ${ }^{15}$

Dari sini dinilai bahwa suatu penelitian untuk mengetahui kinerja guru yang sudah mendapat tunjangan profesi kaitannya dengan kemampuan perlu dilakukan ${ }^{16}$. Karena penilaian kinerja guru yang mengajar merupakan bagian penting dari seluruh proses pembelajaran di suatu sekolah demi meningkatkan mutu dan kualitas mengajar seorang guru.

\section{Sistem Work From Home}

Penyebaran virus Covid-19 ini tidak hanya memberikan dampak yang besar bagi sektor ekonomi dan industri, namun juga pada dunia pendidikan. Demi merealisasikan usaha pencegahan penyebaran virus Covid-19, WHO memberikan rekomendasi pemberhentian segala kegiatan yang berpotensi menimbulkan kerumunan masyarakat luas sementara waktu ${ }^{17}$. Maka pemerintah berbagai Negara yang terjangkit virus ini termasuk pula Indonesia, mengambil kebijakan dengan meliburkan seluruh aktivitas pendidikan tatap muka. Dampaknya, pemerintah dan lembaga terkait harus memberikan solusi alternatif mengenai keberlangsungan proses pendidikan bagi peserta didik maupun mahasiswa yang tidak bisa melaksanakan proses pendidikan seperti biasanya. ${ }^{18}$

Sistem Work From Home (WFH), atau yang biasa disebut dengan bekerja dari rumah merupakan anjuran pemerintah bagi masyarakat Indonesia khususnya. Maka salah satu jalan keluar yang dapat diambil selama masa darurat Covid-19 adalah belajar menggunakan media daring. ${ }^{19}$ Menurut Moore, Dickson-Deane, \& Galyen, pembelajaran daring merupakan pembelajaran yang menggunakan jaringan internet dengan kemampuan untuk memunculkan berbagai jenis interaksi pembelajaran. ${ }^{20}$ Dari sini dinilai masih banyak cara yang harusnya dapat dikembangkan oleh guru demi mengoptimalkan proses belajar.

Namun, pembelajaran yang dilaksanakan secara jarak jauh dengan sistem internet ini juga memiliki kendala yang menghampiri masyarakat. Lokasi guru dan siswa yang terpisah saat melaksanakan pembelajaran membuat para guru tidak bisa mengawasi secara langsung

\footnotetext{
15 Susanto, 200.

${ }^{16}$ Kartowagiran, "Kinerja guru profesional (Guru pasca sertifikasi)," 465.

${ }^{17}$ Firman Firman dan Sari Rahayu, "Pembelajaran Online di Tengah Pandemi Covid-19," Indonesian Journal of Educational Science (IJES) 2, no. 2 (2020): 81.

${ }^{18}$ Agus Purwanto, "Studi Eksplorasi Dampak Work From Home (WFH) Terhadap Kinerja Guru Selama Pandemi Covid-19,” EduPsyCouns: Journal of Education, Psychology and Counseling 2, no. 1 (2020): 2.

19 Yulita Pujilestari, "Dampak Positif Pembelajaran Online Dalam Sistem Pendidikan Indonesia Pasca Pandemi Covid-19," 'ADALAH 4, no. 1 (2020): 53.

${ }^{20}$ Firman dan Rahayu, "Pembelajaran Online di Tengah Pandemi Covid-19," 82.
} 
perkembangan para siswa selama proses pembelajaran. ${ }^{21}$ Dampak lainnya yang dirasakan para guru yaitu tidak semua mengerti betul cara mengaplikasikan berbagai fitur dan teknologi media sosial sebagai sarana belajar. Kebanyakan dari para guru sangat memerlukan pendampingan dan pelatihan terlebih dahulu. ${ }^{22}$ Maka hendaknya penelitian ini dilakukan demi melihat kinerja para guru selama sistem pembelajaran online yang dilakukan di SMK Purnawarman Purwakarta.

SMK Purnawarman Purwakarta adalah sekolah yang sudah terakreditasi A. Yayasan ini berkembang dibawah Yayasan Pendidikan Purnawarman, dan berdiri pada tahun 1977. Pendirinya adalah bapak H.Sarwoko SH. Sekolah ini memiliki berbagai jurusan yang terbilang lengkap, diantaranya; keahlian Akuntansi, Administrasi Perkantoran, Pemasaran Perdagangan, Usaha Perjalanan Wisata dan Rekayasa Perangkat Lunak. Berbagai bidang studi keahlian juga diajarkan disini, seperti; bisnis manajemen, seni kerajinan dan pariwisata, teknologi dan informasi serta komunikasi. Masyarakat menilai bahwa sekolah ini cukup berkompeten dalam menghasilkan siswa yang siap kerja, cerdas dan kompetitif serta sekolah yang tertata rapih. ${ }^{23}$

Sebagai salah satu cara yang dilakukan penulis untuk memperkaya khazanah keilmuan mengenai tema yang diangkat adalah dengan memperbanyak referensi atau rujukan. Referensi tersebut berfungsi untuk memperluas dan memperdalam bahasan mengenai tema penelitian, serta menentukan kelayakan penelitian. ${ }^{24}$ Mengenai hal tersebut, penulis mengambil dua kata kunci penting yaitu, 'kinerja mengajar' dan 'pendidikan pada masa pandemi'.

Mengenai literatur yang membahas mengenai Kinerja Mengajar, La Ode Ismail Ahmad menulis jurnal mengenai konsep penilaian pada tahun 2017 dengan judul "Konsep Penilaian Kinerja Guru dan Faktor yang Mempengaruhinya”, ${ }^{25}$ Jurnal ini mengupas konsep penilaian pada kinerja guru serta faktor-faktor yang dapat mempengaruhi hasil penilaian tersebut. Ia juga memaparkan pentingnya guru meningkatkan kualitas kinerjanya dalam pembelajaran demi memenuhi peran penting dalam dunia pendidikan. Selanjutnya, penelitian yang dilakukan oleh Hary Susanto pada tahun 2012 dengan judul "Faktor-Faktor yang Mempengaruhi Kinerja Guru Sekolah Menengah Kejuruan”. ${ }^{26}$ Penelitian ini juga mengemukakan faktor-faktor yang mempengaruhi kinerja guru namun lebih terfokus pada lapangan di SMKN 1 di Kabupaten

\footnotetext{
${ }^{21}$ Firman dan Rahayu, 85.

${ }^{22}$ Purwanto, "Studi Eksplorasi Dampak Work From Home (WFH) Terhadap Kinerja Guru Selama Pandemi Covid-19," 7.

23 "Smk Kejuruan Purnawarman Purwakarta " Siap Kerja - Cerdas - Kompetitif "," diakses 4 Juli 2020 , http://www.patrolinews86.com/2016/09/smk-kejuruan-purnawarman-purwakarta.html.

${ }^{24}$ John W. Creswell, Research design: qualitative, quantitative, and mixed methods approaches, 4th ed (Thousand Oaks: SAGE Publications, 2014), 32.

${ }^{25}$ Ahmad, "Konsep Penilaian Kinerja Guru Dan Faktor Yang Mempengaruhinya"

${ }^{26}$ Susanto, "Faktor-faktor yang mempengaruhi kinerja guru sekolah menengah kejuruan."
} 
Hulu Sungai Selatan Provinsi Kalimantan Selatan, bukan faktor-faktor kinerja guru secara umum. Jurnal lainnya yang berjudul "Kinerja Guru Profesional (Guru Pasca Sertifikasi)” yang ditulis oleh Badrun Kartowagiran pada tahun 2011. ${ }^{27}$ Jurnal ini membahas mengenai kinerja guru yang telah menjalani proses sertifikasi. Penelitian ini juga mencakup responden yang lebih luas, yaitu sejumlah guru pasca sertifikasi di daerah Sleman-Yogyakarta dari sejumlah sekolah.

Sedangkan pada penelitian yang mengangkat tema pendidikan pada masa pandemi adalah "Pembelajaran Online di Tengah Pandemi Covid-19" karya Firman dan Sari Rahayu Rahman dalam Indonesian Journal of Education Sciences pada tahun $2020 .{ }^{28}$ Penelitian ini membahas tentang gambaran pelaksanaan pembelajaran online di prodi Pendidikan Biologi Fakultas Keguruan dan Ilmu Pendidikan Universitas Sulawesi Barat serta upayanya dalam menekan jumlah penyebaran virus Covid-19 yang sedang mewabah. Subjek dari penelitian ini adalah para mahasiswa prodi Pendidikan Biologi di universitas tersebut. Kemudian, jurnal berjudul "Studi Eksploratif Dampak Pandemi Covid-19 Terhadap Proses Pembelajaran Online di Sekolah Dasar" oleh Tim Agus Purwanto pada tahun 2020. ${ }^{29}$ Penelitian ini dilakukan untuk mendapatkan informasi kendala proses belajar mengajar secara online dirumah akibat dari adanya pandemi Covid-19. Responden dari penelitian ini adalah para guru dan orangtua murid di sebuah sekolah dasar di Tanggerang.

Setelah menelusuri beberapa literatur diatas, penulis menunjukkan signifikansi kajian tersendiri mengenai kinerja mengajar guru secara online di SMK Purnawarman Purwakarta belum pernah dilakukan dan perlu untuk dikaji sebagai sumbangsih khazanah keilmuan baru dalam pendidikan khususnya pada sistem online. Penulis berharap, penelitian ini dapat mengisi kekosongan "gap" terkait literatur persoalan yang dibahas.

\section{Metode Penelitian}

Jenis penelitian yang digunakan adalah penelitian campuran atau mix method. Penelitian ini bertujuan untuk mengetahui kinerja mengajar guru dengan sistem online pada masa pandemi di SMK Purnawarman Purwakarta, maka objek penelitian itu sendiri adalah kinerja mengajar guru dengan menggunakan asesmen kinerja. Penilaian kinerja seorang guru merupakan bagian penting dari seluruh proses kinerja guru yang bersangkutan. Menurut

\footnotetext{
${ }^{27}$ Kartowagiran, "Kinerja guru profesional (Guru pasca sertifikasi)."

${ }^{28}$ Firman dan Rahayu, "Pembelajaran Online di Tengah Pandemi Covid-19."

${ }^{29}$ Purwanto, "Studi Eksplorasi Dampak Work From Home (WFH) Terhadap Kinerja Guru Selama Pandemi Covid-19."
} 
Martinis Yamin dan Maisah yang dikutip dalam sebuah jurnal, disana mengatakan bahwa penilaian kinerja tenaga kependidikan dapat dilakukan melalui beberapa sumber: (1) penilaian atas diri sendiri; (2) penilaian oleh siswa; (3) penilaian oleh rekan sejawat; dan (4) penilaian oleh atasan langsung. ${ }^{30}$ Maka pada penelitian ini penulis akan meneliti kinerja mengajar guru dari sumber penilaian atas diri sendiri dan penilaian oleh atasan langsung. Teknik pengumpulan data yang digunakan di antaranya;

1. Angket. Sebagai data variabel pokok dengan menggunakan aplikasi google form. Angket ini dibuat dengan pilihan jawaban tertutup berupa skala likert dengan pilihan jawaban: Sangat Sesuai, Sesuai, Kurang Sesuai, Tidak Sesuai, dan Sangat Tidak Sesuai. Angket ini disebarkan kepada para Guru di SMK Purnawarman Purwakarta yang seluruhnya berjumlah 40 orang. Namun penulis hanya mengambil sample sejumlah 22 orang guru dikarenakan beberapa kendala.

2. Wawancara. Wawancara secara langsung dilakukan kepada Kepala Sekolah dan Kepala Bagian Kurikulum Sekolah sebagai teknik pengumpulan data kualitatif. Wawancara menggunakan pertanyaan terbuka seperti:Menurut bapak, bagaimana efektifitas pelaksanaan KBM melalui media daring?

a. Bagaimanakah hasil pembelajaran yang didapatkan?

b. Bagaimanakah evaluasi kinerja guru melakukan KBM melalui sistem daring?

3. Dokumentasi. Berupa data sekolah yang didapat dari salah satu guru yang mengajar di sekolah. Data ini menyajikan jumlah siswa, guru beserta staf yang ikut bekerja di SMK Purnawarman

Rancangan penelitian ini menggunakan rancangan metode campuran Sekuensial Eksplanatori, yang mana data kualitatif dapat menerangkan lebih lanjut atau memperkuat data kuantitatif awal. ${ }^{31}$ Penyajian hasil dari penelitian ini berupa analisis deskriptif kuantitatif yang dikolaborasikan dengan deskriptif analisis data kualitatif.

\section{Penyusunan Instrumen}

Instrumen penelitian berupa 16 pertanyaan tertutup dengan bentuk skala likert yang disebar melalui aplikasi google form. Aplikasi ini dipilih karena dapat disebarkan dengan mudah melalui link terkait kepada responden melalui berbagai media sosial. Enam belas pertanyaan ini dibentuk berdasarkan komponen standar kompetensi guru menurut Suparilan

\footnotetext{
${ }^{30}$ Susanto, "Faktor-faktor yang mempengaruhi kinerja guru sekolah menengah kejuruan," 200.

${ }^{31}$ Creswell, Research design, 299.
} 
dalam bukunya Guru Sebagai Profesi pada pembahasan mengenai Penilaian Kinerja. Tertulis bahwa standar kompetensi guru dibagi dalam 3 komponen saling terkait, yaitu:

1. Pengelolaan Pembelajaran

2. Pengembangan Profesi

3. Penguasaan Akademik ${ }^{32}$

Kemudian, ketiga komponen tersebut terdiri atas kompetensi yang menunjukkan indikasi dari kompetensi dasar penilaian seorang guru. Kompetensi ini meliputi 7 kompetensi dasar sesuai dengan Peraturan Pemerintah RI No. 19 tahun 2005 bulir ke-25. Diantaranya:

1. Penyusunan rencana pembelajaran

2. Pelaksanaan interaksi belajar-mengajar

3. Penilaian prestasi belajar peserta didik

4. Pelaksanaan tindak lanjut hasil penilaian prestasi belajar peserta didik

5. Pengembangan profesi

6. Pemahaman wawasan kependidikan

7. Penguasaan bahan kajian akademik sesuai dengan mata pelajaran yang diajarkan. ${ }^{33}$

Berdasarkan komponen dan kompetensi tersebut, disusunlah 16 item pertanyaan yang disusun berdasarkan favorable-unfavorable. Setiap pertanyaan memiliki bobot skor maksimal berupa 5 poin dan nilai minimal berupa 1 poin.

\section{Hasil dan Pembahasan}

Setelah Menteri Pendidikan dan Kebudayaan, Nadiem Makarim mengeluarkan Surat EdaranNomor 4 Tahun 2020 tanggal 24 Maret 2020 tentang Pelaksanaan Kebijakan Pendidikan dalam masa darurat penyebaran virus Covid-19 yang di antaranya tercantum pada poin kedua yang berisikan ketentuan proses belajar dari rumah dapat dilakukan masyarakat, diantaranya;

1. belajar dari rumah dilakukan agar para siswia tetap mendapat pengalaman belajar yang bermakna tanpa harus mematok kesuksesan dengan cara melihat hasil seluruh capaian kurikulum untuk kenaikan kelas maupun kelulusan;

2. belajar dari rumah dapat difokuskan pada Pendidikan kecakapan hidup khususnya mengenai pandemi Covid-19;

\footnotetext{
${ }^{32}$ Ahmad, "Konsep Penilaian Kinerja Guru Dan Faktor Yang Mempengaruhinya," 134.

${ }^{33}$ Ahmad, 135.
} 
3. aktivitas dan tugas pembelajaran dari rumah dapat divariasikan sesuai minat dan kondisi masing-masing, termasuk mempertimbangkan kesenjangan akses/fasilitas belajar di rumah;

4. guru hendaknya memberikan bukti atau produk aktivitas belajar dari rumah berupa umpan balik yang bersifat kualitatif dan berguna tanpa diharuskan memberi skor/nilai kuantitatif. ${ }^{34}$

Kebijakan dari kementerian Pendidikan tersebut juga diikuti oleh Bapak Uyat Sudaryat, ST. sebagai kepala sekolah SMK Purnawarman Purwakarta. Dia memberlakukan pembelajaran daring (online) kepada siswa yang tentunya membuat jajaran guru harus melakukan sistem work from home yaitu mengajar siswa dilaksanakan secara jarak jauh dengan sistem internet.

Dari hasil wawancara dengan bapak Uyat, di tengah kegiatan atau di tengah perjalanan pandemi Covid-19 ini membuat anak termasuk guru dan semuanya di SMK Purnawarman menjadi salah satu tantangan karena bagaimanapun juga kegiatan belajar mengajar harus berjalan $^{35}$. Menurut pengamatan dia serta pendapat dari para guru mengatakan bahwa pembelajaran daring (online) tersebut dirasa kurang efektif, pun oleh Bapak Riyadi selaku Kepala Bagian Kurikulum Sekolah. Dia berpendapat bahwa pembelajaran daring, walaupun ada hasil tapi secara tujuan utama Pendidikan tidak tercapai. Namun semua jajaran pendidik di sekolah berusaha melakukan yang terbaik dengan terus mengikuti kebijakan pemerintah yang ada. Penyampaian materi atau kegiatan belajar mengajar seringnya dilakukan melalui aplikasi WhatsApp, tapi ada juga guru yang menggunakan Google Form, Google Classroom, dan Webex. ${ }^{36}$ Kepala sekolah menambahkan bahwa inti dari pengajaran adalah antara guru dan siswa itu ada komunikasi. ${ }^{37}$ Menurut Muhamad Ibtissam Han, meskipun komunikasi memiliki peran yang netral, tetapi komunikasi yang baik dapat membuat sebuah proses interaksi menjadi lebih baik, ${ }^{38}$ termasuk dalam hal ini proses pembelajaran.

\footnotetext{
34 "SURAT EDARAN MENDIKBUD NO 4 TAHUN 2020 TENTANG PELAKSANAAN KEBIJAKAN PENDIDIKAN DALAM MASA DARURAT PENYEBARAN CORONA VIRUS DISEASE (COVID- 19 ) Pusdiklat Pegawai Kementerian Pendidikan dan Kebudayaan," diakses 4 Juli 2020, https://pusdiklat.kemdikbud.go.id/surat-edaran-mendikbud-no-4-tahun-2020-tentang-pelaksanaan-kebijakanpendidikan-dalam-masa-darurat-penyebaran-corona-virus-disease-covid-1-9/.

${ }^{35}$ Uyat Sudaryat, ST., "Hasil Wawancara bersama Kepala Sekolah”, pada hari Sabtu tanggal 20 Juni 2020 di SMK Purnawarman Purwakarta, J1. Jend. A . Yani No.172 Cipaisan Purwakarta Provinsi Jawa Barat 41113

${ }^{36}$ Riyadi Solihin, S.Sos, "Hasil Wawancara Bersama Kepala Bagian Kurikulum Sekolah", pada hari Sabtu tanggal 20 Juni 2020 di SMK Purnawarman Purwakarta

${ }^{37}$ Uyat Sudaryat, ST., "Hasil Wawancara bersama Kepala Sekolah"

38 Muhammad Ibtissam Han, "Representasi Konflik Ibu Tunggal dan Anak dalam Film Susah Sinyal," KOMUNIKA: Jurnal Dakwah dan Komunikasi 12, no. $2 \quad$ (27 Juli 2018): 256, https://doi.org/10.24090/komunika.v12i2.1306.
} 
Mengenai absensi kehadiran untuk para guru hanya dipantau melalui penugasan kepada siswa. Hal ini disampaikan oleh pak Riyadi bahwa secara kedinasan kurikulum tidak ada absen untuk para guru, hanya dilihat dari penugasan. ${ }^{39}$ Sejalan dengan itu bapak Uyat juga mengatakan kehadiran dalam melaksanakan pembelajaran online ini guru juga, setelah di check untuk mencapai $100 \%$ dari performa dan hasil pengajaran ini agak terkendala, tapi sekolah selalu berusaha bagaimana untuk bapak ibu guru bisa memaksimalkan pembelajaran online ini sesuai dengan kemampuannya. ${ }^{40}$

Berdasarkan data penelitian yang telah diolah, maka peneliti menerbitkan hasil sebagaimana yang terpapar pada diagram dibawah ini:

\section{Diagram Batang 1. Pemaparan prosentase hasil angket kinerja mengajar guru perindividu}

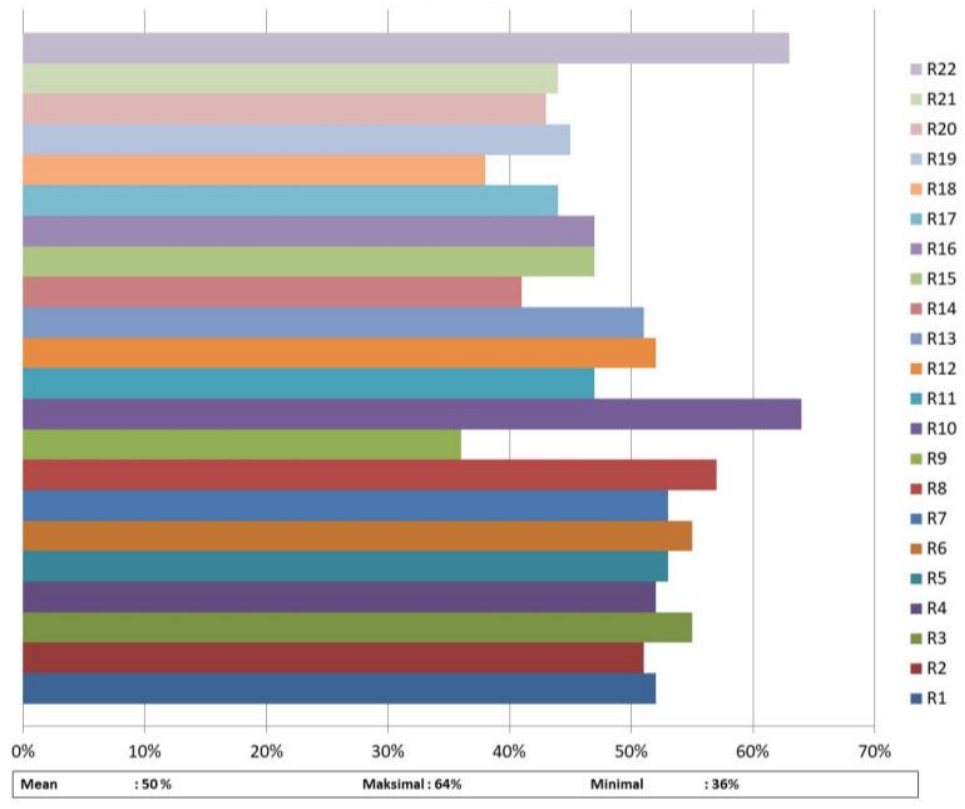

Diagram tersebut menunjukkan keterangan kinerja mengajar guru di SMK Purnawarman berdasarkan prosentase jawaban angket per-individu. Tercatat bahwa prosentase tertinggi dari kinerja guru hanya sekitar $64 \%$ dari jumlah keseluruhan. Sedangkan kinerja guru terendah sekitar $36 \%$ dari jumlah prosentase.

Jika ditelisik dari responden pertama, menunjukkan angka prosentase lebih dari 50\%, responden selanjutnya dinilai mengalami hal yang sama hingga pada responden ke-10 dengan jumlah prosentase minimal sebanyak $36 \%$ hasil kinerja. Perbedaan yang kontras pada responen

\footnotetext{
${ }^{39}$ Riyadi Solihin, S.Sos, "Hasil Wawancara Bersama Kepala Bagian Kurikulum Sekolah”

${ }^{40}$ Uyat Sudaryat, ST., "Hasil Wawancara bersama Kepala Sekolah"
} 
selanjutnya yang mengalami jumlah prosentase maksimal yaitu $64 \%$ hasil kinerja. Sedangkan responden lain memiliki hasil prosentase dengan jumlah yang beragam dan tidak konstan.

Jadi, data menunjukkan hasil rata-rata kinerja guru dalam mengajar dengan sistem online hanya sebesar 50\% dari kinerja maksimal para guru. Secara keseluruhan hasil kinerja tidak ada yang melebihi batas $70 \%$. Ini berarti kinerja guru dalam mengajar dianggap kurang maksimal dikarenakan berbagai kendala yang terjadi pada tiap individu.

Bapak Uyat Sudaryat menjelaskan tentang kendala yang ditemui ketika menerapkan pembelajaran daring. Dia menegaskan bahwa pihak sekolah berusaha untuk memaksimalkan segala hal dalam menghadapi pembelajaran di sekolah dengan cara daring walaupun pada pelaksanaannya hanya bisa mengikuti kondisi yang terjadi. ${ }^{41}$

Sebagai kepala sekolah, bapak Uyat juga memberikan kendala-kendala yang berpengaruh besar akan hasil pembe;ajaran sistem online ini, diantaranya:

1) Sebagian guru yang belum begitu paham tentang penggunaan IT.

2) Tidak semua murid yang mayoritas tinggal di pinggiran memiliki fasilitas teknologi seperti handhone dan laptop. Bahkan ada anak yang sama sekali belum memiliki ponsel Android di rumah.

3) Kemampuan orang tua membeli kuota internet demi memenuhi tututan aplikasi yang dibutuhkan.

Kemudian tersaji hasil prosentase data per item yang diajukan oleh peneliti sebagai berikut:

Diagram Batang 2. Berupa pemaparan prosentase hasil jawaban perjumlah instrumen

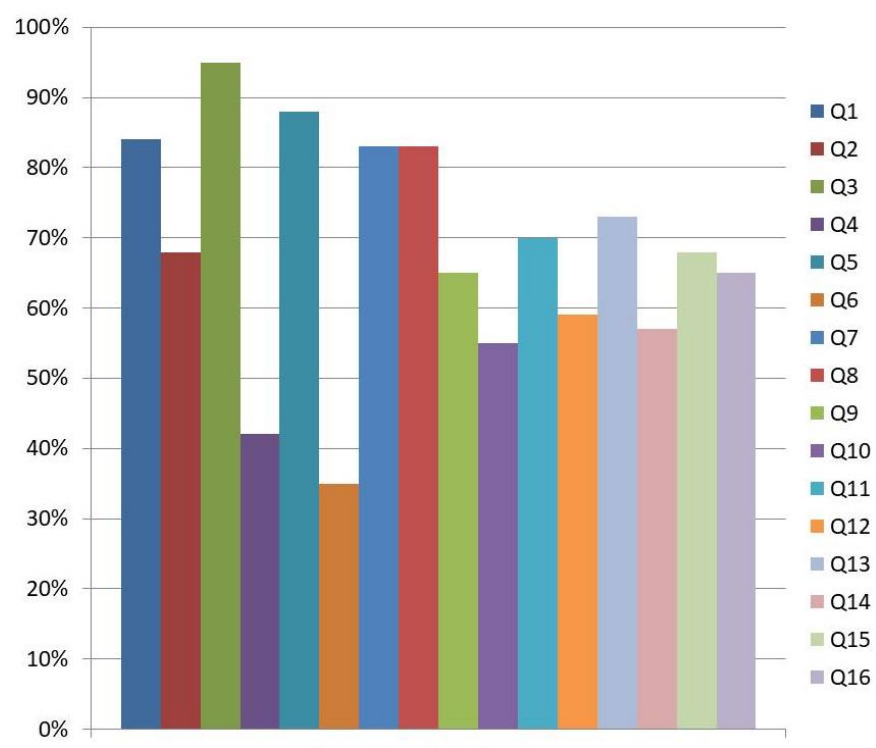

${ }^{41}$ Uyat Sudaryat, ST., "Hasil Wawancara bersama Kepala Sekolah" 
Hasil pengolahan data perjenis pertanyaan mendapatkan prosentase terbesar pada kesesuaian para guru menggunakan Grup pada aplikasi WhatsApp (Q3) untuk menunjang komunikasi yang baik selama dilakukannya kegiatan belajar mengajar di kelas daring dengan porsi $95 \%$. Ini menunjukkan para guru telah melakukan upaya semaksimal mungkin untuk menjalin komunikasi dan interaksi pada proses pembelajaran. Sedangkan para guru terlihat mengeneralisir keberhasilan belajar siswa dari hasil ujian online (Q6), maka hal ini menjadi skor prosentase terendah sebesar 35\%. Ujian dengan sistem online merupakan upaya yang paling memungkinkan untuk dilakukan namun tidak dapat menjadi acuan keberhasilan yang murni, mengingat para siswi jauh dari pengawasan guru selama masa ujian berlangsung. Hal ini diikuti oleh keterampilan guru dalam penguasaan kelas, sebagian guru menganggap bahwa penguasaan kelas sudah tidak penting dilakukan pada pembelajaran sistem online (Q4) yang mendapatkan prosentase sebesar $42 \%$. Hasil tersebut membuktikan bahwa kurangnya pemahaman guru bahwa penguasaan kelas online juga merupakan hal penting yang harus diperhatikan. Hal ini pun dapat terjadi dikarenakan berbagai kendala yang ada pada setiap individu guru.

Analisa demikian juga diperkuat oleh penuturan Bapak Kepala Sekolah yaitu bapak Uyat bahwa hasil kegiatan pembelajaran dan ujian akhir serta sarana untuk menyampaikan seluruh informasi berkaitan pembelajaran, SMK Purnawarman Purwakarta memanfaatkan keberadaan Web Sekolah.

Pihak sekolah juga memaksilamkan fungsi web Sekolah untuk menampung semua hasil kegiatan pembelajaran dan kegiatan ujian akhir atau asesmen yang disampaikan kepada siswa. Dengan memaksimalkan web pihak akademik dan kepala sekolah dapat memantau melihat proses pembelajaran daring tersebut. Web ini dimaksimalkan untuk di dalamnya ada bahan evaluasi kepada anak melalui PAT (Penilaian Akhir Tahun) online. Tentunya hal ini dibuat karena memang kebutuhan yang ingin disampaikan kepada peserta didik sehingga informasi secara menyeluruh bisa tersampaikan. Kemudian hasil ujian yang kami himpun dari peserta didik dalam asesmen atau penilaian ini para siswa masing-masing mengisi hasil ujiannya dan memang itulah hasilnya bahwa kemampuan peserta didik itu. Karena memang itu hasil pembelajaran yang kurang maksimal atau memang hanya menggunakan daring sehingga pemahaman anak dalam menjawab semua soal itu, seperti itulah. Tapi yang terjadi tentunya pihak sekolah harus menyikapi juga bahwa ini tahun 'maklum'. Hasil tugas ujian anak berapapun, itulah hasilnya dan kami juga bapak ibu guru di sekolah secara keseluruhan melihat 
hasil nilai diatas rata-rata tapi kalau muncul untuk sampai mencapai KKM, kami belum penyesuaian. Itulah barangkali kesiapan bapak ibu guru bahwa selain hasil nilai yang murni pada pelaksanaan PAT ini juga ditambahkan dengan nilai-nilai harian sehingga hasilnya dalam raport itu tidak ada yang dibawah KKM, semua di atas KKM karena di rata-ratakan dan ditambah-tambahkan sehingga nilai tidak kurang dari KKN." 42

Sejalan dengan hal ujian dan kenaikan kelas diatas, pemerintah juga telah mengeluarkan Surat Edaran Nomor 4 Tahun 2020 tanggal 24 Maret 2020 tentang Pelaksanaan Kebijakan Pendidikan dalam masa darurat penyebaran virus Corona ${ }^{43}$ yang tercantum pada poin ketiga dan keempat bahwa ujian sekolah untuk kelulusan dilaksanakan dengan ketentuanketentuan yang sudah berlaku.

\section{Kesimpulan}

Dari hasil penelitian yang telah diperoleh, maka penulis menyimpulkan bahwa; Pertama, Rata-rata kinerja guru dalam mengajar dengan sistem online hanya sebesar 50\% dari kinerja maksimal para guru. Secara keseluruhan hasil kinerja tidak ada yang melebihi batas $70 \%$. Ini berarti kinerja guru dalam mengajar dianggap kurang maksimal dikarenakan berbagai kendala yang terjadi pada tiap individu. Sehingga pembelajaran jarak jauh ini dinilai kurang efektif, walaupun pembelajaran ini memberikan hasil namun tujuan pendidikan yang utama belum tercapai. Hal tersebut dikarenakan beberapa faktor-faktor seperti masih banyaknya guru yang belum begitu paham dengan penggunaan aplikasi teknologi modern dari smartphone atau laptop. Kemudian jarak yang jauh tentunya juga memunculkan kendala guru melakukan interaksi secara maksimal.

Kemudian, berbagai dampak yang muncul dari diberlakukannya sistem work from home (WFH) terhadap kinerja mengajar guru di SMK Purnawarman Purwakarta di antaranya para guru semakin tahu sedikit pengaplikasian IT untuk proses pembelajaran. Hal ini terbukti dari penggunaan guru terhadap aplikasi WhatsApp untuk menunjang komunikasi yang baik selama dilakukannya kegiatan belajar mengajar di kelas daring dengan porsi 95\%. Ini menunjukkan para guru telah melakukan upaya semaksimal mungkin untuk menjalin komunikasi dan interaksi pada proses pembelajaran. Namun, menjadi hal yang sulit saat harus memberikan penilaian prestasi belajar peserta didik dengan objektif. Dikarenakan kendala dalam proses

\footnotetext{
${ }^{42}$ Uyat Sudaryat, ST., "Hasil Wawancara bersama Kepala Sekolah"

43 "SURAT EDARAN MENDIKBUD NO 4 TAHUN 2020 TENTANG PELAKSANAAN KEBIJAKAN PENDIDIKAN DALAM MASA DARURAT PENYEBARAN CORONA VIRUS DISEASE (COVID- 19) Pusdiklat Pegawai Kementerian Pendidikan dan Kebudayaan."
} 
pembelajaran yang mana tidak semua anak terfokus dengan belajar, dan juga proses saat mengerjakan ujian itu sendiri. Alhasil, para guru terlihat menggeneralisir keberhasilan belajar siswa dari hasil ujian online, maka hal ini menjadi skor prosentase terendah sebesar 35\%. Kinerja guru dalam penguasaan kelas dan pembuatan persiapan mengajar juga perlu diperhatikan, tidak hanya formalitas saja.

\section{Saran}

Adapun untuk peneliti berikutnya yang akan membahas mengenai pembelajaran dengan sistem online, saya menyarankan beberapa hal. Pertama, penelitian dapat terfokus pada dampak yang dialami para siswa maupun orang tua terhadap pembelajaran online. Kedua, penelitian mengenai kinerja guru juga dapat dilakukan di jenjang sekolah lain seperti SD atau SMP sederajat. Ketiga, penelitian juga dapat dilakukan di daerah lain yang lebih memungkinkan untuk mendapatkan jaringan, mengingat salah satu kendala pada penelitian ini adalah keterbatasan jaringan internet yang masuk ke daerah. Terakhir, penulis berharap bahwa penelitian-penelitian yang telah dilakukan oleh beberapa peneliti mengenai dampak pembelajaran online dapat menjadi pertimbangan dalam pemilihan kebijakan mengenai sistem pendidikan, khususnya di Indonesia. 
Syarah Busyra, Lutfiah Sani

\section{Daftar Pustaka}

Ahmad, Laode Ismail. "KONSEP PENILAIAN KINERJA GURU DAN FAKTOR YANG MEMPENGARUHINYA.” Idaarah: Jurnal Manajemen Pendidikan 1, no. 1 (14 Juni 2017). https://doi.org/10.24252/idaarah.v1i1.4133.

Creswell, John W. Research design: qualitative, quantitative, and mixed methods approaches. 4th ed. Thousand Oaks: SAGE Publications, 2014.

Darmalaksana, Wahyudin. "Corona Hadis." Fakultas Ushuluddin UIN Sunan Gunung Djati Bandung, 2020.

"WhatsApp Kuliah Mobile." Fakultas Ushuluddin UIN Sunan Gunung Djati Bandung, 2020.

Firman, Firman, dan Sari Rahayu. "Pembelajaran Online di Tengah Pandemi Covid-19." Indonesian Journal of Educational Science (IJES) 2, no. 2 (2020): 81-89.

Han, Muhammad Ibtissam. "Representasi Konflik Ibu Tunggal dan Anak dalam Film Susah Sinyal." KOMUNIKA: Jurnal Dakwah dan Komunikasi 12, no. 2 (27 Juli 2018): 24156. https://doi.org/10.24090/komunika.v12i2.1306.

$\mathrm{He}, \mathrm{Wu}$, Guandong Xu, dan S. E. Kruck. "Online IS education for the 21 st century." Journal of Information Systems Education 25, no. 2 (2019): 1.

Kartowagiran, Badrun. "Kinerja guru profesional (Guru pasca sertifikasi)." Jurnal Cakrawala Pendidikan 3, no. 3 (2011).

Mahase, Elisabeth. Coronavirus: covid-19 has killed more people than SARS and MERS combined, despite lower case fatality rate. British Medical Journal Publishing Group, 2020.

Panigrahi, Ritanjali, Praveen Ranjan Srivastava, dan Dheeraj Sharma. "Online learning: Adoption, continuance, and learning outcome-A review of literature." International Journal of Information Management 43 (2018): 1-14.

Pujilestari, Yulita. "Dampak Positif Pembelajaran Online Dalam Sistem Pendidikan Indonesia Pasca Pandemi Covid-19." 'ADALAH 4, no. 1 (2020).

Purwanto, Agus. "Studi Eksplorasi Dampak Work From Home (WFH) Terhadap Kinerja Guru Selama Pandemi Covid-19." EduPsyCouns: Journal of Education, Psychology and Counseling 2, no. 1 (2020): 92-100.

Raisyifa, Destia Nur, dan Nani Sutarni. "Pengaruh kinerja mengajar guru terhadap motivasi belajar siswa." Jurnal Pendidikan Manajemen Perkantoran (JPManper) 1, no. 1 (2016): 90-98.

Sc, Alodia. "Dasar Dasar Proses Belajar Mengajar Oleh Nana Sudjana Penyunting Harry Suryana." Diakses 4 Juli 2020. https://www.academia.edu/11365221/Dasar_dasar_proses_belajar_mengajar_Oleh_N ana_Sudjana_penyunting_Harry_Suryana.

"Smk Kejuruan Purnawarman Purwakarta " Siap Kerja - Cerdas - Kompetitif "." Diakses 4 Juli 2020. http://www.patrolinews86.com/2016/09/smk-kejuruan-purnawarmanpurwakarta.html.

"SURAT EDARAN MENDIKBUD NO 4 TAHUN 2020 TENTANG PELAKSANAAN KEBIJAKAN PENDIDIKAN DALAM MASA DARURAT PENYEBARAN CORONA VIRUS DISEASE (COVID- 1 9) - Pusdiklat Pegawai Kementerian Pendidikan dan Kebudayaan.” Diakses 4 Juli 2020. https://pusdiklat.kemdikbud.go.id/surat-edaran-mendikbud-no-4-tahun-2020-tentangpelaksanaan-kebijakan-pendidikan-dalam-masa-darurat-penyebaran-corona-virusdisease-covid-1-9/.

Susanto, Hary. "Faktor-faktor yang mempengaruhi kinerja guru sekolah menengah kejuruan." Jurnal Pendidikan Vokasi 2, no. 2 (2012). 
Wilder-Smith, Annelies, dan David O. Freedman. "Isolation, quarantine, social distancing and community containment: pivotal role for old-style public health measures in the novel coronavirus (2019-nCoV) outbreak." Journal of travel medicine 27, no. 2 (2020): taaa020. 
Syarah Busyra, Lutfiah Sani 